\title{
Public-Private Partnerships, Cooperative Agreements, and the Production of Public Services in Small and Rural Municipalities
}

\author{
by Robert D. Mohr, University of New Hampshire, \\ Steven Deller, University of Wisconsin-Madison, and \\ John Halstead, University of New Hampshire
}

\begin{abstract}
Using data from approximately 1,000 small and mostly rural municipalities from Illinois, New Hampshire, and Wisconsin, we study choices in production arrangements over a wide range of services, and examine a variety of contracting options available to local governments. The data reveal that municipalities often rely on contracts to provide an extensive list of services.
\end{abstract}

The use of for-profit contractors and cooperative agreements with other governments correlates negatively with population. Nonetheless, small municipalities are less likely to use competitive bidding processes, compare costs between production options, and report that privatization produces savings. Other factors, such as median income, rural geography, and ideology, show statistically significant associations with contracting choices.

Respondents generally consider themselves "satisfied" with services provided by contract, although satisfaction levels are lower than those associated with self-provision. Satisfaction with services provided by other governments is lower than satisfaction with services provided by private contractors. This suggests that small municipalities encounter no tradeoff in service quality directly attributable to for-profit contractors.

\footnotetext{
The authors thank Kai Filion for research assistance, Karen Conway, Kai Filion, Bob Tannenwald, and seminar participants at the University of New Hampshire and the Federal Reserve Bank of Boston for helpful comments, Robin A. Johnson and Norman Walzer for sharing the Illinois Municipal Survey data, Peter Girard for collecting and cataloguing the New Hampshire Municipal Survey data, and the New England Public Policy Center at the Federal Reserve Bank of Boston for supporting this research through its visiting scholars program.
} 
Many small and rural local governments face the stresses of national or regional economic downturns and their own economic stagnation and decline. Others experience population growth and demands to provide additional services to new constituents. These local governments also face declining state and federal support, and antipathy toward either expanding traditional revenue sources such as the local property tax or exploring alternative sources of local revenues such as user fees and charges. Small and rural local governments therefore feel pressure to find more efficient ways to provide necessary services.

One option is "privatization," wherein a municipality uses competitive bidding to contract out the production of services to for-profit firms. This option has yielded numerous documented successes in urban settings, but may pose a number of potential problems for smaller, rural communities. Such public-private partnerships require clearly delineated and enforceable contracts, enough qualified contractors to allow for a competitive bidding process, and the managerial capacity to supervise contractor performance. The smallest municipalities may well lack sufficient scale to satisfy these criteria. In a series of studies looking at the managerial capacity of smaller and rural governments, Honadle (1981, 1983, 1985, and 2001) documents that many small towns are run by citizen volunteers and a small staff of employees.

If privatization is not a feasible alternative for producing a particular service in a small municipality, a cooperative agreement with another government might be. Lackey, Freshwater, and Rupasingha (2002) argue that such agreements offer a number of advantages, including "increased local decision-making capacity, retention of local identity, increased access to external resources, economies of scale, cost-effectiveness, protection for resource-dependent economies, and greater political influence through strength in numbers" (p. 138). Despite these benefits, however, much of the literature perceives intergovernmental cooperation as a relatively rare event (Cigler 1994).

This study considers the choices that small and rural municipalities face: providing a service themselves, entering into an agreement with a profit or not-for-profit contractor, or entering into an agreement with another government or authority. The research uses survey data from some 1,000 municipalities in Illinois, New Hampshire, and Wisconsin. All the included municipalities are small—more than a third have populations of less than 
1,000 , and more than half have populations of less than 5,000—and a significant proportion are rural.

Neither intergovernmental cooperation nor privatization has been studied extensively in small or rural municipalities. Prior studies have typically examined privatization decisions for a small number of services, or cooperation between municipalities for unusual events, such as the creation of an industrial park. The data here cover 59 different common municipal functions.

Finally, most existing studies focus on a single production option-usually privatization, or, less commonly, cooperative agreements among governments. This study examines the full range of options available to rural governments seeking nontraditional alternatives to service provision and funding.

By studying small rural communities, a broad range of services, and a menu of different options for producing those services, we hope to shed light on some issues that are only incompletely understood. For example, the data can highlight the very different constraints faced by small and rural communities compared with their larger urban or suburban counterparts. The data can also provide detailed insight into how factors like fiscal stress, prior experiences, and future expectations might shape production decisions.

Our analysis of the data can also provide insight into the relationship between privatization and intergovernmental cooperation, and the relative outcomes of those two choices. In fact, this study is among the first to examine the levels of satisfaction associated with different forms of service provision.

\section{Background}

The focus of this research—the mix of options for service production among small and rural communities— builds on prior studies of privatization and intergovernmental cooperation. The bulk of the large and interdisciplinary literature on alternative options for service delivery focuses narrowly on privatization. The consensus, although not universal, view is that when municipalities privatize services, they benefit through lower costs and greater efficiency. 
For example, Savas's widely cited research $(1982,1987)$ argues that contracts with private, for-profit contractors generate significant cost savings across a wide range of services. ${ }^{1}$ Based on this and other evidence, López-de-Silanes, Shleifer, and Vishny (1997) argue that the remaining "obvious question [is] why does private contracting remain much less popular than in-house provision" (p. 448).

We hypothesize that part of the answer to that question relates to economies of scale. For small and rural towns, a lack of scale economies both increases the potential benefits of public-private partnerships and makes the effective administration of such contracts more problematic. Kodrzycki (1994) identifies some of the advantages enjoyed by private contractors, including greater flexibility, and economies of scale and scope among contractors who service numerous communities. . All those benefits would be especially pronounced in smaller communities, which face high unit costs when producing a service themselves. Indeed, Kodrzycki's empirical results confirm a negative correlation between population and a tendency to privatize.

However, Kodrzycki (1994) also points out that a move to public-private partnerships introduces new contracting and monitoring costs. Municipal administrators need to deal with tasks like doing audits, maintaining quality standards, and responding to cost overruns. While these added responsibilities may be well within the capabilities of professional administrators in large cities, Brown and Potoski (2003) argue that contract management is "a highly complex process requiring multiple types of expertise from public managers" ( $p$. 154). The very small municipalities studied here might be unable to provide such expertise for contract administration. Therefore, correlations between privatization or other forms of contracting and population might be very different for the smallest communities.

Because a lack of managerial capacity may make it difficult for the smallest municipalities to benefit fully from privatization, our work also considers the degree to which such municipalities avail themselves of a second option: providing services through cooperative agreements among governments. For example, most local governments have

\footnotetext{
${ }^{1}$ For additional evidence supporting this view, see Perry and Babitstky (1986), Ferris and Graddy (1991), Stein (1990), and Miranda and Lerner (1995). A number of more recent studies argue that the claim for cost savings may be overstated. These studies include Hirsch (1995), Boyne (1998), Lavery (1999), and Klitgaard and Teverton (2003).
} 
formal and informal agreements to lend support to each other for emergency services. The possibilities for such collaboration are much broader, however, and only a few authors, such as Lackey, Freshwater, and Rupasingha (2002) and Agranoff and McGuire (2004), provide in-depth discussions of collaboration. Furthermore, Warner and Hefetz (2002) point out that the literature generally does not jointly consider cooperation and privatization as differing options for service production. Intergovernmental cooperation has not received as broad attention as privatization decisions, despite the fact that such agreements might offer similar benefits.

Moreover, very little empirical work has looked closely at the experiences of very small municipalities using cross-sectional data. ${ }^{2}$ Studies typically draw on surveys of the International City and County Management Association (such as Greene 1996; Ferris 1986; Ferris and Graddy 1986; Warner and Hefetz 2002) or the Census of Governments (such as Kodrzycki1994; Lopez-de-Silanes, Shleifer, and Vishny 1997).

Such analyses have three central limitations. First, they lack detail in terms of the history of the public-private partnerships. That is, they treat partnerships or contracts that have been in place for years the same as relatively new partnerships. That means that they might use today's characteristics to explain or predict patterns of decisions made years earlier.

Second, many of these studies assume a dichotomous dependent variable—often in the form of a yes/no response. This masks the continuous nature of many public-private partnerships. For example, municipalities may contract for road construction but retain maintenance responsibilities in-house. Or state-mandated social services may remain purely in the public sector, while municipalities contract supplemental and more focused services, such as those for domestic abuse, to nonprofits. The form of contracting out may also differ: another municipality or a for-profit firm may produce the contracted services.

Third, and most relevant to our work, surveys of municipalities typically exclude municipalities with fewer than 10,000 residents, or provide data at only the county level.

\footnotetext{
${ }^{2}$ A number of case studies study smaller communities. Particularly relevant to this study are Lackey, Freshwater, and Rupasingha (2002), who study cooperation among counties in Tennessee, and JossartMarcelli and Musso (2005), who conduct an extensive study of "make or buy" decisions for a set of southern California cities.
} 


\section{Data}

The primary data for this study come from three separate surveys of municipalities in Illinois, Wisconsin, and New Hampshire. The first of these was the 1995 Illinois Municipal Privatization Questionnaire, which served as a model for later studies in Wisconsin (1997) and New Hampshire (2004). In each state, researchers at one of the state's public universities (Western Illinois University, University of Wisconsin-Madison, and the University of New Hampshire) and a local governments association (Illinois Municipal League, Wisconsin League of Municipalities, and the New Hampshire Local Government Center) distributed the survey jointly. The municipal associations played a key role in identifying contact lists of municipal officials, which allowed us to target the surveys directly to key municipal decision makers, and to generate reasonable response rates for a relatively long survey instrument.

Each survey targeted the entire population of municipalities in its state. The Illinois survey produced 516 responses, the Wisconsin survey produced 452 responses, and the New Hampshire survey produced 138 responses, yielding response rates of 40 percent, 73 percent, and 59 percent, respectively. Johnson and Walzer (1996, 1998), Deller, Hinds, and Hinman (2001), and Girard, Mohr, Deller, and Halstead (2007) provide detailed descriptions of the survey design and implementation for each survey.

The three surveys contained nearly identical questions. Although the impetus for the surveys was an interest in privatization, the survey's first section also elicited information about cooperation with other governments. This section asked respondents to give a subjective evaluation of the local government's current fiscal condition and a prediction about its fiscal prognosis. These questions asked survey respondents the degree to which revenues are sufficient to either expand services or reduce taxes.

Ensuing questions in this section asked how each of 82 different services is provided, and the level of satisfaction with the arrangement (on a five-point Likert scale). Choices in service provision included "municipal provision" (either "entirely" or "in part"), "another government or authority," or "private" (either "for-profit" or "nonprofit"). This section of the survey concluded by asking general questions about plans for future 
outsourcing, the government's role in providing services to other municipalities, experiences with public-private partnerships of nearby municipalities, and experiences with bidding on contracts.

While the survey covers 82 different services, municipalities provide a number of these only rarely. If their government does not provide a particular service, respondents are instructed not to answer the questions. To avoid drawing inferences from very small samples, we excluded 21 services with less than a 40 percent response rate among completed surveys.

We also excluded gas and electricity production. Privatization of these services typically occurs through the granting of a franchise, and municipalities' jurisdiction to grant such franchises differs significantly by state.

Because our study focuses on the tradeoffs that small and rural municipalities face, we also excluded data from municipalities with populations exceeding 50,000. The remaining data cover 1,083 municipalities and 59 services. After excluding non-responses for particular questions, this produces a dataset of 36,605 municipality-service combinations.

\section{Methods}

To analyze the survey data, we used a descriptive analysis followed by three empirical models. In the descriptive analysis we report survey means. The first two empirical analyses identify municipal characteristics that correlate with a municipality's current choices of service provision and its plans to increase privatization. In the final empirical model, we identify the relationship between choice of production method and reported satisfaction by local government officials.

The descriptive analysis starts by reporting survey results that highlight the different constraints faced by small and rural communities. It then reports on the frequency with which municipal governments rely on different forms of service provision, by service. The descriptive analysis also explores how those patterns differ by municipality size. Finally, the descriptive results identify one outcome associated with service provision: respondents' 
reported satisfaction with particular services, which allows us to compare mean satisfaction scores by service and form of provision.

While a descriptive analysis can reveal a number of informative correlations, it does not control for interactions between variables. Empirical models allow us to draw stronger inferences about current and expected patterns of public-private partnerships and cooperative agreements among governments, and satisfaction with those arrangements.

The first empirical model considers the relationship between characteristics of a municipality and the choice of a particular form of service provision. This model uses the full dataset of 36,605 municipality-service combinations. We look at three specific partnership strategies: contracting with private for-profit firms, contracting with another unit of government, and, finally, any form of service delivery other than "your employees entirely." The dependent variables take on a value of one if the town uses that particular partnership strategy, and zero otherwise.

We group our independent variables into five sets of factors that we hypothesize will correlate with decisions on contracting: measures of scale $(P)$, indicators of rural communities $(R)$, measures of stress $(S)$, a focus on efficiency $(E)$, and a measure of local ideology (I). Equation (1) represents this empirical model:

$\operatorname{Prob}\left(\operatorname{prov}_{j m}=1\right)=\Phi\left(\alpha+\beta_{1} P_{m}+\beta_{2} R_{m}+\beta_{3} S_{m}+\beta_{4} E_{m}+\beta_{5} I_{m}+\gamma Z_{j}+\delta G_{m}+\varepsilon_{j t}\right)$

where the subscripts $j$ and $m$ refer to the service and municipality (respectively), $\beta_{1}-\beta_{5}$ each represent a vector of coefficients associated with a particular set of dependent variables, $Z_{j}$ represents a full set of service-specific indicator variables, and $G_{m}$ represents a vector of dummy variables capturing state-specific effects.

We estimate the model three times-once for each of three partnership strategies used to identify the dependent variable. Because of the discrete nature of the dependent variables, we use a logit estimator. Because all the independent variables (except the service dummies, $Z_{j}$ ) are measured at the municipal level, we cluster the standard errors. ${ }^{3}$

\footnotetext{
${ }^{3}$ One drawback of using the municipality-service combination as the unit of observation for studying the relationship between town characteristics and form of service provision is that it gives more weight to towns
} 
To proxy for the constraints that the smallest municipalities face because of a lack of scale economies, we include population, population squared, and median income in the measure of $P$. The smallest or most impoverished municipalities-which lack the scale to efficiently provide a full range of services-might have the most to gain from employing external contracts, with either other governments or private contractors. These municipalities also face some of the largest obstacles in using contracts effectively. Because the surveys represent different years, we use the U.S. Census Bureau's estimated population for the survey year $(1995,1997$, and 2004). The 2000 census is the source for the measures of median income and population density.

Even after controlling for scale, rural communities might be different from their urban counterparts. Geographic dispersion may make it harder for these communities to attract a sufficient number of bids from private contractors, or even to forge contracts with neighboring communities. The measure of rural characteristics $(R)$ includes two variables: population density, and a dummy variable identifying municipalities that are close to an urban area (noted as Metropolitan Statistical Area dummy in Tables 5, 6, and 7, below). We expect both measures to correlate positively with all types of contracting.

As our introduction suggests, decisions to contract or privatize may be a response to fiscal stress and difficulty in providing services to a growing population. Two independent variables capture these forms of stress $(S)$ : survey responses to the question asking if revenues are adequate, and a measure of population growth (in percentage terms) derived from comparing the 1990 and 2000 census. Population growth indicates greater pressure on town officials to adapt to changing conditions. ${ }^{4}$ We hypothesize that such a measure will correlate positively with all forms of contracting.

We capture current fiscal stress through an indicator that takes the value of one if the municipality reports "inadequate" revenues. A positive relationship between this indicator and any form of contracting would be consistent with the hypothesis that towns use

that provide more services. The estimations in this section are not weighted. An alternative specification, used in Kodrzycki (1994) and Warner and Hefetz (2002), creates an index variable by municipality for the propensity to use a particular form of production. This alternative ensures that all municipalities have equal weight, but cannot control as effectively for the particular mix of services provided.

${ }^{4}$ The New Hampshire survey also includes a question asking if population growth has affected the municipality's ability to provide services. Our pooled estimation does not include this question. 
contracting as a response to fiscal stress. A negative coefficient, on the other hand, might be evidence that prior decisions to contract out a service-which may, in turn, identify municipalities that use more sophisticated public management techniques—correlate with better current fiscal health.

The next set of variables, $E$, intends to capture the degree to which town officials focus on efficiency. If towns routinely compare costs and use competitive bidding, then we view this as an indication that these municipalities have implemented systems designed to control costs. We hypothesize that these types of towns are more likely to use contracts with either private contractors or other governments.

The percentage of Republican voters in the previous gubernatorial election provides an indication of local ideology $(I)$. We found election returns in the preceding gubernatorial election in Illinois State Board of Elections (1994), Wisconsin Legislative Reference Bureau (1996), and New Hampshire Elections Division (2004). Only New Hampshire provides these data at a municipal level. We use county-level returns for Wisconsin and all parts of Illinois outside Cook County. If a municipality crosses a county line, we assign it to the county that contains the plurality of the municipality's population. For Cook County, which includes Chicago, the Illinois State Board of Elections reports returns at the township level, and we use those data to get a more disaggregated measure of ideology. ${ }^{5}$

Voting patterns-which correlate with privatization decisions in the county-level analysis by López-de-Silanes, Shleifer and Vishny (1997)—may reflect ideological predisposition toward private markets and against government provision. We hypothesize that a higher percentage of Republican voters corresponds to a greater likelihood that a municipality will use private, for-profit contractors, and a lower likelihood that it will have a cooperative agreement with another government or authority.

The final independent variables are fixed-effects variables for services and geographic regions. The service variables—one for each of the 59 services-control for otherwise unobserved characteristics of the individual services. The geographic indicators identify the three states. We identify Cook County separately from the rest of Illinois.

\footnotetext{
${ }^{5}$ A township may include parts of several villages (municipalities). If a village crosses a township line, we use a weighted average based on the number of 2006 polling stations in each township.
} 
An important limitation of cross-sectional results-like those derived from estimating equation (1) - is the potential for endogeneity. All variation in the model comes from differences between towns; we do not observe a decision within a town to change provision of any particular service. Results from such a cross-sectional estimation can be biased if the explanatory variables are causally linked to past production decisions. Current fiscal stress, and administrative practices such as comparing costs and using competitive bids, may associate with prior procurement and production decisions. This limitation applies to our study as well as other cross-sectional analyses, and we cannot fully mitigate it without long-duration panel data. Thus results from the pooled cross-sectional model should be viewed as indications of correlation, rather than evidence of causality.

The data used here do offer a dependent variable that is less likely to raise issues of endogeneity, and therefore allows stronger causal inferences. We asked survey respondents not only about current practices but also about future plans-that is, whether their municipality plans to increase the number of services privatized.

The second empirical model estimates equation (1) using stated plans to increase privatization as a dependent variable. The independent variables remain mostly unchanged. Here we measure both present and expected future fiscal stress, and control for prior privatization experiences. We first use expected stress, on the hypothesis that officials base future plans on expected future conditions. We then include current stress in a separate estimation, to allow for the possibility that plans for future privatization are a reaction to current conditions.

To control for a municipality's existing experiences, we also add one other explanatory variable: an index variable based on the number of services privatized. While using plans to increase privatization as a dependent variable reduces the likelihood of bias, this model also has some limitations. One is that we now focus exclusively on privatization, instead of the full menu of production options. Another is that the dependent variable elicits information on general plans for privatization rather than on specific services.

While the first two empirical models identify factors associated with different methods of service production, they provide no indication of perceived quality. To gain insight into this basic question, we estimate an ordered probit model—to identify the 
relationship between measures of population, income, rural geography, fiscal stress, sensitivity to costs, and ideology with reported levels of satisfaction, which we denote $\sigma_{j m}$. The empirical model corresponding to this relationship is represented in equation (2):

$\sigma_{j m}=\Phi\left(\alpha+\beta_{1} P_{m}+\beta_{2} R_{m}+\beta_{3} S_{m}+\beta_{4} E_{m}+\beta_{5} I_{m}+\beta_{\phi} p r o v_{j m}+\gamma Z_{j}+\delta G_{m}+\varepsilon_{j t}\right)$

Because satisfaction is measured with an increasing Likert scale, we use an ordered probit estimator. The dependent variables include the same measures used with the first empirical model. In this case, however, we view these variables as control variables. Our interest is in the relationship between the indicators of particular forms of service provision, prov $_{j m}$, and satisfaction, measured relative to "private, for profit," the omitted group.

Two comparisons are particular interesting. First, we want to know if production by a municipality's own employees is associated with higher levels of satisfaction. We hypothesize that it will be-in part because of the bias of respondents, who may well have direct involvement in managing provided services. However, if satisfaction proves to be lower even with this bias, it would be evidence that privatization yields benefits in terms of service quality.

A second comparison, which avoids the bias respondents have for their own employees, observes how satisfaction with services produced by private contractors compares with satisfaction with services produced by contract with another government or authority.

\section{Descriptive Results}

\section{Characteristics of Municipalities}

Issues such as fiscal stress, a lack of managerial capacity, and a general lack of scale may influence the choices that small and rural governments make regarding the provision of services. Table 1 summarizes information on the municipalities we surveyed. The three left-hand columns present data by town size, the next three columns give summary statistics 
by state and year, and the final column provides totals. The data reveal a number of ways that smaller municipalities face different constraints.

Fiscal health correlates with town size: the smallest governments are slightly less likely to describe a revenue shortfall that requires a reduction in services. Respondents from larger municipalities are also more likely to hold a pessimistic view of the next five years. Although the majority of respondents in all local governments foresee adequate revenues, 10 percent of the largest municipalities anticipate service reductions. ${ }^{6}$ These results suggest that smaller municipalities might feel less pressure to turn to external contracts as a strategy for addressing short-term fiscal stress. When asked about future plans for privatization, the smallest local governments are least likely to consider expanding privatization.

In cases where municipalities do turn to private contractors, the data reveal that the process and outcomes differ significantly by municipal size. The smallest municipalities are least likely to report comparing costs between public and private provision, using a competitive bidding process, and generating a sufficient number of bids from private contractors. Perhaps because of these reasons, respondents from smaller municipalities are also least likely to report that privatization produces cost savings. Write-in responses describing instances of privatization suggest that smaller, rural local governments use privatization as a matter of practicality rather than as a cost-saving strategy. The write-in responses describe scenarios such as hiring out tasks to avoid investing in equipment and paying for a full-time specialist.

\section{Patterns in the Provision of Services}

Table 2 reports on the frequency with which municipal governments rely on different methods of service production. The rows of the table define all 59 services, and the columns identify aggregate responses from all three surveys. This information shows the

\footnotetext{
${ }^{6}$ Because the surveys reflect conditions from three different years, and the summary statistic is an unweighted mean, such a result might be driven by changing economic conditions. The same pattern-that the smallest towns are least likely to report inadequate revenues—holds for both Wisconsin and New Hampshire. Illinois does not show a notable correlation between population and measures of fiscal stress.
} 
proportion of all municipalities that indicate particular forms of service production (conditional on whether they provide the service).

The top section of Table 2 identifies services such as payroll administration and personnel services, which municipalities' own employees nearly always provide. The remaining three sections identify services in which municipalities differ significantly in how they produce those services. These sections list services where municipalities generally: (1) produce the service through either municipal employees or privatization; (2) produce the service through either municipal employees or a cooperative agreement, and (3) employ all three forms of service production.

This descriptive information alone reveals a number of patterns. First, both privatization and cooperative agreements are quite common. For about half of the 59 services, more than 20 percent of the municipalities use one of these two forms of production. More than 80 percent of the municipalities rely on another government for the production of at least one service. Programs for the elderly, delinquent tax collection, title record/plot map maintenance, animal shelter operation, and processing of tax bills are most often provided through intergovernmental cooperation. These alternatives certainly merit study, even for small and rural communities.

The results in Table 2 also raise the question of whether cooperative agreements should be viewed as an alternative to privatization. While the descriptive results do not allow a formal test of this relationship, they do indicate that many of the services most often provided through cooperative agreements are also among the least often contracted to forprofit contractors. (Ranking services according to the proportion of municipalities employing a particular method of provision and deriving a rank correlation produces a Spearman correlation coefficient of -0.26 , which is statistically significant at the 5 percent level.) Services that are most often provided by private, for-profit contractors tend to be closer to the bottom of the list of services most often contracted to another government. Municipalities often share responsibilities such as managing (which includes training and communication) first responders-fire, police, and emergency medical services—with other municipalities, but almost never delegate them to private, for-profit entities. 
The last section of Table 2 identifies 11 services where municipalities do use both privatization and contracting with other governments significantly. It seems likely that many municipalities face a menu of feasible options for providing these services, which include tax assessing, insect/rodent control, and traffic signal maintenance.

Table 3 provides further insight into the conditions under which a municipality is likely to enlist a private contractor or another governmental entity in producing a particular service. This analysis identifies the proportion of municipalities using a particular method of service production — by municipal size—for 33 services that are often produced by either private contractors or another government or municipality. ${ }^{7}$

The results show that smaller towns appear much more likely than their larger counterparts to use contracts with other governments. The smallest municipalities use contracts with other governments more often than the largest municipalities for 26 of the 33 services in Table 3. Privatization does not have a clear population trend: the relationship between municipality size and the proportion of governments relying on for-profit contractors appears to vary by the type of service. Larger municipalities use private contractors more often than their smaller counterparts for 14 of the 33 services in Table 3 .

\section{Satisfaction with Contracted Services}

The survey also asked respondents to indicate their satisfaction with services, using a five-point Likert scale ranging from "very satisfied" to "not satisfied." Table 4 reports the mean satisfaction levels, by form of service provision, for each of the services in Table 3 . Nearly all the response means are close to 3 , indicating that respondents consider themselves "satisfied" with the services provided, regardless of the form of provision.

Provision by a municipality's own employees generally associates with the highest level of satisfaction. This may indicate that the various forms of contracting involve a tradeoff in service quality, and suggests that a desire for better service is not a key motivation for privatization or intergovernmental cooperation. As noted, the results may

\footnotetext{
${ }^{7}$ We select services provided by at least 500 municipalities, and where at least 20 percent of municipalities providing a service choose to do so through a contract with either a for-profit firm or another government or municipality.
} 
also simply reflect the bias of respondents, who may directly supervise the provision of services.

Although respondents may be biased toward their own employees, they are less likely to have systematic biases in their relative satisfaction with other forms of service production. In particular, comparing satisfaction between services produced by other governments and private contractors offers some indication as to whether the profit motive of private contractors creates some tradeoff in terms of quality. This preliminary look at the raw data shows that satisfaction levels with services produced by other governments and by private contractors are roughly comparable.

\section{Empirical Results}

\section{The Relationship between Municipality Characteristics and Service Production}

Our first empirical model considers the relationship between the characteristics of a municipality and its choice of a particular form of service production (see Table 5). Nearly all the coefficient signs are consistent across specifications. The correlation between municipal attributes and the tendency to contract out services does not particularly depend on the form of contracting. The same types of municipalities that enter into contracts with private contractors also enter into agreements with other governments.

Population correlates negatively with contracting decisions. The smallest municipalities do appear to have the most to gain from the scale, scope, and flexibility that external contracts offer. This finding is consistent with Kodrzycki (1994), who argues that privatization patterns are largely "bottom up" (p. 32), and also finds negative and significant coefficient estimates on population. Our results indicate that this conclusion extends to even the smallest municipalities, although the relationship appears to be nonlinear.

Median income correlates positively with all forms of contracting. And although population density is always insignificant, the indicator for municipalities within a Metropolitan Statistical Area (MSA) supports the conclusion that rural municipalities provide fewer services using outside contracts. 
Surprisingly, neither measures of stress (fiscal stress and population growth) nor the use of competitive bidding processes correlate strongly with contracting decisions. The coefficients all have insignificant (at the 5 percent level) associations with the use of contracts.

Municipalities that compare costs between public and private production, however, are less likely to use private contractors. While contrary to our hypothesis, this finding is consistent with the earlier observation that the respondents to our surveys appear to use privatization as a matter of practicality, rather than as a cost-saving strategy. Our measure of ideology - the percentage of Republican voters in the previous gubernatorial electionreinforces the conclusion that contracting decisions, particularly those with for-profit contractors, are driven by more than a focus on efficiency. Ideology matters: it is positively associated with the use of for-profit contractors, as well as contracting broadly defined.

Kodrzycki (1994) finds significantly lower rates of privatization in New England-a finding our results do not replicate. The omitted state, New Hampshire, shows a greater propensity to use private, for profit contractors than Wisconsin and most of Illinois do. This finding — viewed in conjunction with Kodrzycki's result—may mean that New England communities are catching up to contracting trends (recall that the New Hampshire survey occurred several years after the Illinois and Wisconsin data had been collected).

The differing conclusions might also be driven by differences between the larger municipalities observed by Kodrzycki and the smaller municipalities observed here, or by differences in the way "privatization" is measured. We do find support for Kodrzycki's finding when using the broader measure of external contracts—such as agreements with other governments, or even any service provided in a way other than the municipality's "employees entirely."

Without an appropriate instrument, we cannot formally test the hypothesis that some underlying set of characteristics determines both privatization and contracts with other governments. However, the data appear consistent with this hypothesis. The types of services that municipalities contract with other governments typically differ from the types of services they privatize-suggesting that they are not direct substitutes. At the same time, the town features that correlate with privatization decisions also correlate with the decision 
to engage in contracts with other governments.

\section{The Relationship between Municipal Characteristics and Plans for Future Privatization}

Table 6 provides the results of the logit estimations that relate town characteristics to plans to increase privatization. The coefficient estimate on population is positive and significant, while the squared population term has a negative and significant coefficient. This suggests a positive, but decreasing, association between town size and planned increases in privatization. This may partly reflect more sophisticated planning processes of larger municipalities. High-growth areas are also more likely to plan increases in privatization.

Indicators for rural counties, self-reported fiscal stress, a municipality's sensitivity to costs, and ideology all have a statistically insignificant relationship with plans to increase privatization (at the 5 percent level). It is difficult to interpret these findings further. It may be that either the question about increasing privatization or the explanatory variables are too general to identify specific patterns in privatization decisions. For example, Republican voting in a gubernatorial election may not correlate sufficiently with a town's fiscal ideology. It is also possible that the results are consistent with a long-run equilibrium. Municipalities have already chosen their optimal bundle of provision choices based on their observable characteristics, and plans for future changes represent responses to specific and otherwise unobservable changes at the local level.

\section{The Relationship between Forms of Service Provision and Satisfaction}

While the results in Tables 5 and 6 identify factors associated with different forms of service provision, they provide no indication of perceived quality. To gain insight into this basic question, we estimate an ordered probit model to identify the relationship between measures of population, income, ruralism, fiscal stress, sensitivity to costs, and ideology and reported levels of satisfaction (see Table 7). As in Table 5, we control for the particular service, along with an additional set of dummy variables to control for the type of partnership. 
The majority of the control variables-including population, income, sensitivity to costs, and ideology—have statistically insignificant relationships with satisfaction. The measure of fiscal stress has a negative and significant coefficient. The variables of most interest in Table 7 are the last four indicators, which measure satisfaction with the form of service provision relative to "private, for profit," the omitted group. As suggested in Table 4, satisfaction with "your employees entirely" is higher than satisfaction associated with any other form of service provision. Furthermore, the difference between "private, for profit" and "other government or authority" is statistically significant at the 1 percent level. This suggests that, in a comparison that avoids the bias respondents have for their own employees, private contractors offer comparable or better-quality service relative to their public counterparts.

\section{Conclusion}

Despite the extensive literature examining public-private partnerships in the delivery of public services, few studies have focused on smaller and rural municipalities. This research attempts to address this shortcoming. Using three surveys, we document that even the smallest municipalities use a range of partnerships, including contracting with private, for-profit firms, nonprofit organizations, and other governments.

We find that even in a sample of communities where the population is typically less than 10,000 , contracting in all its forms is a "bottom-up" phenomenon that associates negatively with population. Nonetheless, small municipal governments face noteworthy constraints: a significant number of respondents express concern about receiving insufficient bids. This is an important finding, because for outsourcing to be effective, a sufficient number of entities need to compete for the contract. When a critical mass of competing entities is not present, outsourcing may be an unrealistic or second-best option. It is perhaps not surprising, then, that smaller municipalities are less likely to report cost savings associated with private contracts.

The survey data do not directly suggest how small and rural local governments might overcome challenges in administering public-private contracts. However, some questions 
added to the New Hampshire version of the survey suggest that greater collaboration among municipalities - in the form of shared information or jointly managed contracts-merits further study. While municipalities often work together to produce services, they do not seem to cooperate in developing and managing outside contracts.

For example, the New Hampshire survey asked respondents whether bordering municipalities had privatized services, and a large majority of respondents answered "don't know." Even with the great variety of services contracted out, only few local officials were aware of their neighbors' actions. In fact, only 3 of the 138 surveyed municipalities responded that the decisions of their neighbors affected their own decision to privatize services. Of those, one respondent cited learning from another town's experience, and two referred to combining their needs to collectively bid out a contract.

The New Hampshire responses show that small municipalities might benefit from greater collaboration-expanding from collaboration in providing services to collaboration in managing external contracts. Sharing information would be the simplest way that municipalities could help each other out. A more sophisticated form of collaboration would involve banding together to create larger contracts. Multi-community contracts for service provision might more easily merit the expense of setting up competitive bidding processes and generating a sufficient number of bids. Such contracts could also allow communities to consolidate oversight expenses and other costs associated with the use of private contractors.

The potential for greater use of ad hoc collaborative arrangements may also be a salient issue in other New England states. The region's characteristic individualism is sometimes reflected in a propensity for municipal governments to "go it alone." Institutional barriers, such as uncoordinated laws, a lack of cooperation across state agencies, and a lack of infrastructure for sharing information, all contribute to the difficulty of coordinating across governments. ${ }^{8}$ It therefore seems unlikely that the region has fully exploited the benefits of collaborative agreements. At the same time, many of New England's local governments report significant fiscal stress, and state governments—facing

\footnotetext{
${ }^{8}$ Ryan, Fábos, and Allan (2004) study a particular area for collaboration, greenway planning, and show that all of these are significant barriers in New England.
} 
serious fiscal challenges themselves—cannot bail them out. Collaboration is therefore generating growing attention as a cost-saving, efficiency-enhancing option.

Despite the constraints they face and the apparent limits of collaboration, many small communities seem to manage well nonetheless. The smallest communities are least likely to report severe fiscal stress, and are least likely to expect to reduce services in the future. Although their contracting decisions may not always be part of an overall cost-saving strategy, these municipalities use contracts effectively to produce specific and specialized services they cannot produce themselves.

While reported satisfaction associates slightly negatively with population, respondents in small and rural towns generally indicate that they are "satisfied" with the services they receive. In fact, the results of our models suggest that satisfaction with private contractors exceeds satisfaction with the services provided by other governments. 


\section{References}

Agranoff, R., and M. McGuire. 2004. "Another Look at Bargaining and Negotiating in Intergovernmental Management." Journal of Public Administration Research and Theory 14(4): 495-512.

Boyne, G.A. 1998. "Bureaucratic Theory Meets Reality: Public Choice and Service Contracting in U.S. Local Government." Public Administration Review 58(6): 474-84.

Brown, T.L., and M. Potoski. 2003. "Contract-Management Capacity in Municipal and County Governments." Public Administration Review 63(2): 153-64.

Cigler, B. 1994. "Pre-Conditions for Multicommunity Collaboration." In B.A. Cigler, A.C. Jansen, V.D. Ryan, and J.C. Stabler (eds.), Towards an Understanding of Multicommunity Collaboration. Washington, DC: U.S. Department of Agriculture, Economic Research Service.

Deller, S.C. 1998. "Local Government Structure, Devolution, and Privatization.” Review of Agricultural Economics 20(1): 135-54.

Deller, S.C., D.G. Hinds, and D.L. Hinman. 2001. "Local Public Services in Wisconsin: Alternatives for Municipalities with a Focus on Privatization.” Staff paper no. 441. University of Wisconsin-Madison, Department of Agricultural and Applied Economics. http://www.aae.wisc.edu/pubs/sps/pdf/stpap441.pdf.

Ferris, J.M. 1986. “The Decision to Contract Out: An Empirical Analysis.” Urban Affairs Quarterly 22(2): 289-311.

Ferris, J.M., and E. Graddy. 1986. “Contracting Out: For What? With Whom?” Public Administration Review 46(4): 332-44.

Ferris, J.M., and E. Graddy. 1991. "Production Costs, Transaction Costs, and Local Government Contractor Choice.” Economic Inquiry 29(3): 541-54.

Girard, P., R.D. Mohr, S. Deller, and J. Halstead. 2007. "Public-Private Partnerships and Cooperative Agreements in Municipal Service Delivery." Mimeo. Durham: University of New Hampshire.

Greene, J. 1996. "How Much Privatization? A Research Note Examining the Use of Privatization by Cities in 1982 and 1992. Policy Studies Journal 24(4): 632-40.

Hirsch, W. 1995. “Contracting Out by Urban Governments: A Review.” Urban Affairs Review 30(3): 458-72.

Honadle, B.W. 1981. "A Capacity-Building Framework: A Search for Concept and Purpose." Public Administration Review 41(5): 575-80. 
Honadle, B.W. 1983. Public Administration in Rural Areas and Small Jurisdictions: A Guide to the Literature. New York: Garland.

Honadle, B.W. 1985. "Small Is Different: Public Administration as if Rural Areas and Small Jurisdictions Mattered. Municipal Management (Summer): 179-85.

Honadle, B.W. 2001. Theoretical and Practical Issues of Local Government Capacity in an Era of Devolution. Journal of Regional Analysis and Policy 31(1): 77-90.

Illinois State Board of Elections. 1994. Official Vote: General Election on November 8, 1994. Springfield.

Joassart-Marcelli, P., and J. Musso. 2005. "Municipal Service Provision Choices within a Metropolitan Area." Urban Affairs Review 40(4): 492-519.

Johnson, R.A., and N. Walzer. 1996. "Competition for City Services: Has the Time Arrived? Privatization in Illinois Municipalities." Macomb: Illinois Institute for Rural Affairs. http://www.iira.org/pubsnew/publications/IIRA_RRR_87.pdf.

Johnson, R.A., and N. Walzer. 1998. "Efficiency in County Government: The Role of Intergovernmental Agreements and Privatization." Macomb: Illinois Institute for Rural Affairs. http://www.iira.org/pubsnew/publications/IIRA_Reports_16.pdf.

Klitgaard, R., and G.F. Treverton. 2003. Assessing Partnerships: New Forms of Collaboration. New Ways to Manage series. Washington, DC: IBM Endowment for the Business of Government.

Kodrzycki, Y. 1994. "Privatization of Local Public Services: Lessons for New England." New England Economic Review, May-June: 31-46.

Lackey, S.B., D. Freshwater, and A. Rupasingha. 2002. "Factors Influencing Local Government Cooperation in Rural Areas: Evidence for the Tennessee Valley." Economic Development Quarterly 16(2): 138-154.

Lavery, K. 1999. Smart Contracting for Local Government Services: Processes and Experience. Westport, CT: Praeger.

Lopez-de-Silanes, F.A.A. Shleifer, and R.W. Vishny. 1997. "Privatization in the United States." RAND Journal of Economics 28: 447-71.

Miranda, R., and A. Lerner. 1995. "Bureaucracy, Organizational Tedundancy, and the Privatization of Public Services. Public Administration Review 55(2): 193-200.

New Hampshire Elections Division. 2004. State General Election Summary. Concord: Secretary of State. 
Perry, J. L., and T.T. Babitstky. 1986. "Comparative Performance in Urban Bus Transit." Public Administration Review 46(1): 57-65.

Ryan, R.L., J.G. Fábos, and J.J. Allan. 2006. "Understanding Opportunities and Challenges for Collaborative Greenway Planning in New England." Landscape and Urban Planning 76(1-4): 172-191.

Savas, E.S. 1982. Privatizing the Public Sector: How to Shrink Government. Chatham, NJ: Chatham House.

Savas, E.S. 1987. Privatization: The Key to Better Government. Chatham, N.J.: Chatham House.

Stein, R.M. 1990. "The Budgetary Effects of Municipal Services Contracting: A Principle Agent Explanation. American Journal of Political Science 34(2): 471-502.

Warner, M., and A. Hefetz. 2002. "Applying Market Solutions to Public Services: An Assessment of Efficiency, Equity, and Voice." Urban Affairs Review 38(1): 70-89.

Wisconsin Legislative Reference Bureau. 1996. State of Wisconsin Blue Book, 1995-1996. Madison. 
Table 1. Survey Responses by Size of Municipality

\begin{tabular}{|c|c|c|c|c|c|c|c|}
\hline & $\begin{array}{l}\text { Small } \\
\text { (pop. < } \\
1,000)\end{array}$ & $\begin{array}{l}\text { Medium } \\
(1,000- \\
5,000)\end{array}$ & $\begin{array}{l}\text { Large } \\
\text { (pop. } \\
>5,000)\end{array}$ & $\begin{array}{c}\text { IL } \\
\text { (1995) }\end{array}$ & $\begin{array}{c}\text { WI } \\
\text { (1997) }\end{array}$ & $\begin{array}{c}\text { NH } \\
\text { (2004) }\end{array}$ & $\begin{array}{l}\text { Total (un- } \\
\text { weighted) }\end{array}$ \\
\hline \multicolumn{8}{|l|}{ Rate the current fiscal condition of your municipality. } \\
\hline Adequate revenue and able to reduce taxes & $13 \%$ & $17 \%$ & $19 \%$ & $12 \%$ & $21 \%$ & $15 \%$ & $16 \%$ \\
\hline Adequate revenue, but not able to expand services & $63 \%$ & $57 \%$ & $56 \%$ & $61 \%$ & $59 \%$ & $52 \%$ & $59 \%$ \\
\hline Inadequate revenue, but not reducing services & $21 \%$ & $22 \%$ & $19 \%$ & $22 \%$ & $19 \%$ & $22 \%$ & $21 \%$ \\
\hline Inadequate revenue, reducing services & $3 \%$ & $4 \%$ & $5 \%$ & $4 \%$ & $2 \%$ & $10 \%$ & $4 \%$ \\
\hline \multicolumn{8}{|l|}{$\begin{array}{l}\text { What are the financial prospects of your municipality over the } \\
\text { next five years? }\end{array}$} \\
\hline Adequate revenue and able to reduce taxes & $10 \%$ & $16 \%$ & $14 \%$ & $11 \%$ & $16 \%$ & $15 \%$ & $14 \%$ \\
\hline Adequate revenue, but not able to expand services & $63 \%$ & $55 \%$ & $55 \%$ & $59 \%$ & $60 \%$ & $50 \%$ & $58 \%$ \\
\hline Inadequate revenue, but not reducing services & $20 \%$ & $19 \%$ & $21 \%$ & $22 \%$ & $19 \%$ & $19 \%$ & $20 \%$ \\
\hline Inadequate revenue, reducing services somewhat & $6 \%$ & $9 \%$ & $10 \%$ & $8 \%$ & $5 \%$ & $16 \%$ & $8 \%$ \\
\hline \multicolumn{8}{|l|}{ In the next five years, will your town: } \\
\hline Increase privatization & $3 \%$ & $12 \%$ & $37 \%$ & $18 \%$ & $13 \%$ & $11 \%$ & $15 \%$ \\
\hline Remain the same & $61 \%$ & $52 \%$ & $34 \%$ & $52 \%$ & $48 \%$ & $55 \%$ & $51 \%$ \\
\hline Decrease privatization & $1 \%$ & $2 \%$ & $0 \%$ & $1 \%$ & $0 \%$ & $2 \%$ & $1 \%$ \\
\hline Don't know & $35 \%$ & $35 \%$ & $29 \%$ & $29 \%$ & $39 \%$ & $31 \%$ & $33 \%$ \\
\hline
\end{tabular}




\begin{tabular}{|c|c|c|c|c|c|c|c|}
\hline Has privatization or contracting resulted in cost savings? & & & & & & & \\
\hline Yes, in all instances & $12 \%$ & $15 \%$ & $19 \%$ & $17 \%$ & $15 \%$ & $7 \%$ & $15 \%$ \\
\hline Yes, in some instances & $55 \%$ & $62 \%$ & $72 \%$ & $56 \%$ & $69 \%$ & $63 \%$ & $62 \%$ \\
\hline No & $34 \%$ & $23 \%$ & $9 \%$ & $27 \%$ & $17 \%$ & $30 \%$ & $23 \%$ \\
\hline $\begin{array}{l}\text { Does your municipality compare costs between services provided } \\
\text { by a public agency and a private entity? } \\
\text { (fraction "yes") }\end{array}$ & $68 \%$ & $72 \%$ & $81 \%$ & $68 \%$ & $80 \%$ & $69 \%$ & $73 \%$ \\
\hline $\begin{array}{l}\text { Are municipal contracts with private firms bid competitively? } \\
\text { (fraction "yes") }\end{array}$ & $87 \%$ & $88 \%$ & $94 \%$ & $89 \%$ & $91 \%$ & $84 \%$ & $89 \%$ \\
\hline $\begin{array}{l}\text { Have a sufficient number of private contractors bid on most } \\
\text { municipal services? (fraction "yes") }\end{array}$ & $75 \%$ & $77 \%$ & $81 \%$ & $78 \%$ & $81 \%$ & $63 \%$ & $77 \%$ \\
\hline $\begin{array}{l}\text { Does your municipality provide services for other governments by } \\
\text { contract? (fraction "yes") }\end{array}$ & $12 \%$ & $21 \%$ & $49 \%$ & $23 \%$ & $27 \%$ & $25 \%$ & $25 \%$ \\
\hline Number of respondents & 414 & 392 & 277 & 505 & 441 & 137 & \\
\hline
\end{tabular}


Table 2. Distribution of Service Provision (All Three States)

Services typically provided exclusively by municipal employees

Building security

Building/grounds maint.

Payroll administration

Personnel services

Public relations/info.

Secretarial services

Snowplowing sanding

Street repair/maint.

Traffic control/parking

enforcement

Water distribution
724

860

$\begin{array}{lcccc}\text { Municipal } & \text { Municipal } & \text { Another } & \text { Private, } & \text { Private, } \\ \text { employees } & \text { employees } & \text { govt. or } & \text { for } & \text { not for } \\ \text { entirely } & \text { in part } & \text { authority } & \text { profit } & \text { profit }\end{array}$

$78.5 \%$

$10.0 \%$

$3.6 \%$

$7.6 \%$

$0.2 \%$

$72.8 \%$

$20.0 \%$

$0.3 \%$

$6.5 \%$

$0.3 \%$

940

$92.0 \%$

$4.2 \%$

$0.9 \%$

$3.0 \%$

$0.0 \%$

645

$90.9 \%$

$6.7 \%$

$0.8 \%$

$1.7 \%$

$0.0 \%$

544

$79.4 \%$

$16.2 \%$

$2.2 \%$

$1.7 \%$

$0.6 \%$

748

$92.7 \%$

$5.4 \%$

$0.9 \%$

$1.1 \%$

$0.0 \%$

1,029

$77.1 \%$

$11.0 \%$

$4.1 \%$

$7.4 \%$

$0.5 \%$

1,017

$45.8 \%$

$40.5 \%$

$3.4 \%$

$9.9 \%$

$0.2 \%$

$83.7 \%$

$6.63 \%$

$8.7 \%$

$1.0 \%$

$0.00 \%$

$83.1 \%$

$7.44 \%$

$4.5 \%$

$4.2 \%$

$0.70 \%$

\section{Services frequently privatized}

Vehicles, not emergency or heavy equipment

Bill collection

$15.9 \%$

$1.8 \%$

$12.8 \%$

$0.2 \%$

Building security

474

$62.7 \%$

$13.7 \%$

$8.4 \%$

$15.0 \%$

$0.2 \%$

Commercial solid waste

collection

765

$7.2 \%$

$4.1 \%$

$2.4 \%$

$85.8 \%$

$0.7 \%$ 
Fleet management/vehicle

\begin{tabular}{|c|c|c|c|c|c|c|}
\hline maint. & 708 & $52.4 \%$ & $35.0 \%$ & $0.6 \%$ & $11.4 \%$ & $0.6 \%$ \\
\hline Heavy equipment & 592 & $55.6 \%$ & $27.2 \%$ & $1.7 \%$ & $15.2 \%$ & $0.3 \%$ \\
\hline Inspection/code enforcement & 717 & $70.3 \%$ & $13.5 \%$ & $4.0 \%$ & $11.7 \%$ & $0.4 \%$ \\
\hline Labor relations & 546 & $59.2 \%$ & $23.3 \%$ & $2.6 \%$ & $14.8 \%$ & $0.2 \%$ \\
\hline Legal services & 848 & $12.1 \%$ & $7.0 \%$ & $4.2 \%$ & $75.6 \%$ & $1.1 \%$ \\
\hline Recycling & 862 & $12.3 \%$ & $9.0 \%$ & $8.6 \%$ & $66.7 \%$ & $3.4 \%$ \\
\hline \multicolumn{7}{|l|}{ Residential solid waste } \\
\hline collection & 919 & $15.3 \%$ & $2.2 \%$ & $2.7 \%$ & $79.2 \%$ & $0.5 \%$ \\
\hline Street light operation & 842 & $19.2 \%$ & $10.3 \%$ & $8.0 \%$ & $60.2 \%$ & $2.3 \%$ \\
\hline Street parking lot cleaning & 736 & $73.1 \%$ & $12.2 \%$ & $2.3 \%$ & $11.7 \%$ & $0.7 \%$ \\
\hline Street sweeping & 828 & $71.4 \%$ & $5.0 \%$ & $5.1 \%$ & $18.0 \%$ & $0.6 \%$ \\
\hline Tree trimming/planting & 832 & $34.0 \%$ & $40.3 \%$ & $1.6 \%$ & $22.8 \%$ & $1.3 \%$ \\
\hline Utility billing & 886 & $76.7 \%$ & $6.2 \%$ & $2.8 \%$ & $14.0 \%$ & $0.2 \%$ \\
\hline Utility meter reading & 847 & $73.7 \%$ & $5.8 \%$ & $3.7 \%$ & $16.5 \%$ & $0.4 \%$ \\
\hline Vehicle towing and storage & 613 & $10.8 \%$ & $5.7 \%$ & $7.2 \%$ & $75.7 \%$ & $0.7 \%$ \\
\hline Yard waste collection & 697 & $38.0 \%$ & $19.7 \%$ & $2.0 \%$ & $39.2 \%$ & $1.1 \%$ \\
\hline
\end{tabular}


Table 2. Distribution of Service Provision (cont.)

Services frequently provided through cooperative agreements

Animal control

Crime prevention/patrol

Data processing

Delinquent tax collection

Fire communication

Fire

prevention/suppression

Fire training

Operation and maint. of

recreation facilities

Operation of libraries

Parks landscaping/maint.

Police communication

Police training

Programs for the elderly

Recreation services

Sanitation inspection

Sewage collection

Sewage treatment
Responses
Another govt. or authority
Private, Private, for not for profit profit
786

909

627

749

772

767

749

810

655

856

813

766

436

741

529

806

781
$43.8 \%$

$17.9 \%$

$73.5 \%$

$72.2 \%$

$31.6 \%$

$36.3 \%$

$10.6 \%$

$12.2 \%$

$14.0 \%$

$9.5 \%$

$9.8 \%$

$25.6 \%$

$26.2 \%$

.

$70.7 \%$

$12.3 \%$

$13.2 \%$

$6.3 \%$

$37.9 \%$

$13.2 \%$

$69.3 \%$

$41.3 \%$

$15.9 \%$

$28.6 \%$

$27.8 \%$

$13.1 \%$

$17.7 \%$

$61.3 \%$

$34.6 \%$

$14.7 \%$

$78.7 \%$

$6.5 \%$

$71.6 \%$
$32.9 \%$

$0.5 \%$

$5.5 \%$

$39.8 \%$

$2.3 \%$

$6.0 \%$
$3.3 \%$

$0.2 \%$

$0.0 \%$

$0.7 \%$

$5.1 \%$ 
Tax billing processing

Water treatment

Services with a broad mix of provision options

Ambulance service

Animal shelter operation

Cemetery admin./maint.

Emergency medical service

Emergency vehicles

Insect/rodent control

Sludge disposal

Solid waste disposal

Tax assessing

Title record/plot map

maint.

Traffic signal install./maint.
787

808

$29.5 \%$

$3.8 \%$

$9.7 \%$

$5.2 \%$

$49.2 \%$

$9.0 \%$

$33.4 \%$

$8.2 \%$

$44.2 \%$

$25.4 \%$

$25.8 \%$

$13.8 \%$

$43.5 \%$

$9.40 \%$

$10.1 \%$

$5.1 \%$

$22.6 \%$

$7.5 \%$

805

646

$15.9 \%$

$13.6 \%$

$32.1 \%$

$20.1 \%$

576

$48.4 \%$

$12.3 \%$
$1.9 \%$

$5.4 \%$
$0.5 \%$

$0.9 \%$ 
Table 3. Rates of Cooperative Arrangement and Privatization, by Town Size, for Select Services (Conditional on Providing Service)

\begin{tabular}{|c|c|c|c|c|c|c|}
\hline & \multicolumn{3}{|c|}{$\begin{array}{c}\text { Another government or } \\
\text { authority }\end{array}$} & \multicolumn{3}{|c|}{ Private, for profit } \\
\hline & $\begin{array}{l}\text { Small } \\
(p o p .< \\
1,000)\end{array}$ & $\begin{array}{c}\text { Medium } \\
\text { (pop. } \\
1,000_{-} \\
5,000)\end{array}$ & $\begin{array}{c}\text { Large } \\
(p o p . \\
>5,000)\end{array}$ & $\begin{array}{l}\text { Small } \\
(\text { pop. }< \\
1,000)\end{array}$ & $\begin{array}{c}\text { Medium } \\
\text { (pop. } \\
1,000_{-} \\
5,000)\end{array}$ & $\begin{array}{l}\text { Large } \\
(\text { pop. } \\
>5,000)\end{array}$ \\
\hline Ambulance service & $51.9 \%$ & $36.1 \%$ & $15.6 \%$ & $21.4 \%$ & $16.8 \%$ & $19.8 \%$ \\
\hline Animal control & $40.2 \%$ & $24.1 \%$ & $22.1 \%$ & $7.8 \%$ & $3.5 \%$ & $8.7 \%$ \\
\hline Animal shelter operation & $67.6 \%$ & $51.8 \%$ & $37.1 \%$ & $15.1 \%$ & $15.5 \%$ & $23.4 \%$ \\
\hline Cemetery admin./maint. & $17.3 \%$ & $13.3 \%$ & $9.6 \%$ & $12.0 \%$ & $11.1 \%$ & $14.1 \%$ \\
\hline Commercial solid waste collection & $4.1 \%$ & $2.2 \%$ & $0.5 \%$ & $81.0 \%$ & $86.7 \%$ & $90.4 \%$ \\
\hline Delinquent tax collection & $65.3 \%$ & $51.5 \%$ & $56.2 \%$ & $0.0 \%$ & $0.7 \%$ & $2.0 \%$ \\
\hline Emergency medical service & $55.9 \%$ & $38.0 \%$ & $17.9 \%$ & $10.3 \%$ & $8.1 \%$ & $12.7 \%$ \\
\hline Emergency vehicles & $30.0 \%$ & $15.9 \%$ & $4.4 \%$ & $10.2 \%$ & $16.8 \%$ & $10.0 \%$ \\
\hline Fire communication & $60.6 \%$ & $55.0 \%$ & $26.3 \%$ & $1.8 \%$ & $1.0 \%$ & $0.0 \%$ \\
\hline Fire prevention/suppression & $49.8 \%$ & $36.9 \%$ & $13.3 \%$ & $1.3 \%$ & $0.3 \%$ & $0.0 \%$ \\
\hline Fire training & $48.8 \%$ & $43.2 \%$ & $26.5 \%$ & $2.5 \%$ & $2.2 \%$ & $2.1 \%$ \\
\hline Legal services & $6.1 \%$ & $4.0 \%$ & $2.4 \%$ & $81.9 \%$ & $79.1 \%$ & $63.7 \%$ \\
\hline Operation of libraries & $47.6 \%$ & $31.9 \%$ & $39.1 \%$ & $0.7 \%$ & $0.3 \%$ & $0.5 \%$ \\
\hline Police communication & $56.6 \%$ & $43.3 \%$ & $22.0 \%$ & $3.2 \%$ & $1.2 \%$ & $0.4 \%$ \\
\hline Police training & $59.1 \%$ & $33.8 \%$ & $26.9 \%$ & $3.6 \%$ & $2.2 \%$ & $5.1 \%$ \\
\hline Recycling & $13.6 \%$ & $7.6 \%$ & $4.6 \%$ & $59.3 \%$ & $66.8 \%$ & $74.3 \%$ \\
\hline Residential solid waste collection & $4.7 \%$ & $2.5 \%$ & $0.4 \%$ & $77.4 \%$ & $81.8 \%$ & $78.2 \%$ \\
\hline
\end{tabular}




\begin{tabular}{|c|c|c|c|c|c|c|}
\hline Sanitation inspection & $60.5 \%$ & $44.2 \%$ & $40.8 \%$ & $4.7 \%$ & $3.5 \%$ & $1.5 \%$ \\
\hline Sewage treatment & $9.5 \%$ & $14.7 \%$ & $30.1 \%$ & $2.0 \%$ & $5.0 \%$ & $7.9 \%$ \\
\hline Sludge disposal & $11.6 \%$ & $15.8 \%$ & $31.8 \%$ & $29.0 \%$ & $24.2 \%$ & $23.4 \%$ \\
\hline Solid waste disposal & $12.1 \%$ & $8.2 \%$ & $11.7 \%$ & $69.9 \%$ & $74.0 \%$ & $74.5 \%$ \\
\hline Street light operation & $8.3 \%$ & $9.8 \%$ & $5.3 \%$ & $78.8 \%$ & $54.1 \%$ & $44.7 \%$ \\
\hline Street repair/maint. & $6.9 \%$ & $1.9 \%$ & $0.7 \%$ & $18.3 \%$ & $5.4 \%$ & $4.5 \%$ \\
\hline Street sweeping & $11.7 \%$ & $3.3 \%$ & $1.5 \%$ & $25.2 \%$ & $16.0 \%$ & $14.3 \%$ \\
\hline Tax assessing & $30.4 \%$ & $28.8 \%$ & $47.7 \%$ & $41.7 \%$ & $42.5 \%$ & $16.2 \%$ \\
\hline Tax billing processing & $45.8 \%$ & $45.1 \%$ & $56.2 \%$ & $2.8 \%$ & $1.6 \%$ & $1.4 \%$ \\
\hline Title record/plot map maint. & $63.9 \%$ & $53.9 \%$ & $49.2 \%$ & $15.2 \%$ & $17.4 \%$ & $9.1 \%$ \\
\hline Traffic signal install./maint. & $16.9 \%$ & $27.8 \%$ & $27.3 \%$ & $12.7 \%$ & $13.9 \%$ & $33.3 \%$ \\
\hline Tree trimming/planting & $2.3 \%$ & $1.6 \%$ & $0.8 \%$ & $30.8 \%$ & $18.3 \%$ & $20.2 \%$ \\
\hline Utility billing & $2.2 \%$ & $2.5 \%$ & $4.0 \%$ & $19.7 \%$ & $11.7 \%$ & $9.5 \%$ \\
\hline Utility meter reading & $2.7 \%$ & $3.6 \%$ & $4.9 \%$ & $21.9 \%$ & $14.1 \%$ & $13.0 \%$ \\
\hline Vehicle towing and storage & $18.2 \%$ & $5.2 \%$ & $2.5 \%$ & $65.7 \%$ & $73.3 \%$ & $84.0 \%$ \\
\hline Yard waste collection & $3.2 \%$ & $1.9 \%$ & $1.2 \%$ & $33.9 \%$ & $32.4 \%$ & $50.4 \%$ \\
\hline
\end{tabular}


Table 4. Levels of Satisfaction with Select Services

\begin{tabular}{|c|c|c|c|c|c|}
\hline & $\begin{array}{c}\text { Municipal } \\
\text { employees } \\
\text { entirely }\end{array}$ & $\begin{array}{c}\text { Municipal } \\
\text { employees } \\
\text { in part }\end{array}$ & $\begin{array}{l}\text { Another } \\
\text { government } \\
\text { or authority }\end{array}$ & $\begin{array}{c}\text { Private, } \\
\text { for } \\
\text { profit } \\
\end{array}$ & $\begin{array}{c}\text { Private, } \\
\text { not for } \\
\text { profit } \\
\end{array}$ \\
\hline Ambulance service & 4.5 & 3.8 & 4.2 & 4.0 & 4.4 \\
\hline Animal control & 3.9 & 3.6 & 3.4 & 3.7 & \\
\hline Animal shelter operation & 3.7 & & 3.6 & 3.8 & 3.9 \\
\hline Cemetery admin./maint. & 3.2 & 2.8 & 2.9 & 2.9 & 3.1 \\
\hline Commercial solid waste & 4.4 & 3.8 & & 4.0 & \\
\hline collection & & & & & \\
\hline Delinquent tax collection & 4.3 & 3.9 & 3.9 & & \\
\hline Emergency medical service & 4.5 & 4.1 & 4.1 & 4.0 & 4.3 \\
\hline Emergency vehicles & 3.4 & 2.9 & 3.1 & 2.9 & \\
\hline Fire communication & 4.3 & 4.1 & 4.1 & & 4.3 \\
\hline Fire prevention/suppression & 4.4 & 4.1 & 4.1 & & 4.4 \\
\hline Fire training & 4.4 & 4.2 & 4.1 & & 4.2 \\
\hline Legal services & 4.2 & 4.0 & 4.4 & 4.1 & \\
\hline Operation of libraries & 4.3 & 4.2 & 4.2 & & \\
\hline Police communication & 4.3 & 4.0 & 3.9 & & \\
\hline Police training & 4.2 & 4.2 & 4.1 & & \\
\hline Recycling & 4.2 & 4.0 & 4.1 & 4.1 & \\
\hline Residential solid waste collection & 4.4 & & & 4.1 & \\
\hline Sanitation inspection & 4.2 & 3.7 & 3.6 & & \\
\hline Sludge disposal & 4.3 & 4.2 & 3.9 & 4.0 & \\
\hline
\end{tabular}




\begin{tabular}{|c|c|c|c|c|}
\hline Solid waste disposal & 4.3 & 3.9 & 3.8 & 4.1 \\
\hline Street light operation & 4.4 & 4.0 & 4.1 & 4.1 \\
\hline Street repair/maint. & 4.1 & 3.9 & 4.2 & 4.1 \\
\hline Street sweeping & 4.2 & 3.6 & 3.8 & 3.8 \\
\hline Tax assessing & 4.5 & 4.0 & 3.5 & 4.1 \\
\hline Tax billing processing & 4.5 & 4.3 & 3.9 & \\
\hline Title record/plot map maint. & 4.2 & 3.7 & 3.9 & 3.9 \\
\hline Traffic signal & 4.3 & 4.0 & 3.9 & 3.9 \\
\hline \multicolumn{5}{|l|}{ installation/maintenance } \\
\hline Tree trimming/planting & 4.1 & 3.9 & & 4.0 \\
\hline Utility billing & 4.4 & 4.0 & & 4.1 \\
\hline Utility meter reading & 4.3 & 3.9 & 3.8 & 4.1 \\
\hline Vehicle towing and storage & 4.2 & 3.6 & 3.8 & 3.9 \\
\hline Yard waste collection & 4.3 & 3.8 & & 3.9 \\
\hline
\end{tabular}

Notes: Satisfaction measured according to a 5-point Likert scale. Mean satisfaction levels suppressed if fewer than 30 respondents reported using the method of service provision. 
Table 5. Forms of Service Provision (Logit Model)

\begin{tabular}{|c|c|c|c|}
\hline & $\begin{array}{c}\text { Private, for } \\
\text { profit }\end{array}$ & $\begin{array}{l}\text { Another } \\
\text { government } \\
\text { or authority }\end{array}$ & $\begin{array}{l}\text { Other than } \\
\text { "your } \\
\text { employees } \\
\text { entirely" }\end{array}$ \\
\hline \multirow[t]{2}{*}{ Population (thousands) } & $-0.034 * * *$ & $-0.081 * * *$ & $-0.049 * * *$ \\
\hline & $(3.34)$ & $(7.12)$ & $(5.08)$ \\
\hline \multirow[t]{2}{*}{ Population squared } & 0.0003 & $0.001^{* * * *}$ & $0.001 * * *$ \\
\hline & $(1.23)$ & $(5.12)$ & $(3.15)$ \\
\hline \multirow[t]{2}{*}{ Med. household income } & $0.005 * *$ & $0.007 * * *$ & $0.009^{* * *}$ \\
\hline & $(2.19)$ & $(3.59)$ & $(4.51)$ \\
\hline \multirow[t]{2}{*}{ Population density } & 0.019 & -0.005 & -0.025 \\
\hline & $(0.54)$ & $(0.15)$ & $(1.00)$ \\
\hline \multirow[t]{2}{*}{ MSA dummy } & $0.176 * *$ & 0.099 & $0.134^{*}$ \\
\hline & $(2.24)$ & $(1.15)$ & $(1.91)$ \\
\hline \multirow[t]{2}{*}{ Current stress } & -0.031 & -0.103 & 0.008 \\
\hline & $(0.45)$ & $(1.37)$ & $(0.13)$ \\
\hline \multirow[t]{2}{*}{ Population growth } & 0.001 & $0.002 *$ & 0.001 \\
\hline & $(0.97)$ & $(1.95)$ & $(1.08)$ \\
\hline \multirow[t]{2}{*}{ Compares costs } & $-0.149^{* *}$ & 0.042 & 0.004 \\
\hline & $(2.25)$ & $(0.56)$ & $(0.07)$ \\
\hline \multirow[t]{2}{*}{ Competitive bids } & 0.007 & -0.120 & -0.085 \\
\hline & $(0.07)$ & $(0.95)$ & $(0.97)$ \\
\hline \multirow[t]{2}{*}{$\%$ Republican } & $0.019^{* * * *}$ & -0.001 & $0.010 * *$ \\
\hline & $(4.02)$ & $(0.27)$ & (2.28) \\
\hline
\end{tabular}




\begin{tabular}{lccc}
\hline Illinois, Cook County & -0.208 & $1.632^{* * *}$ & $0.601 * * *$ \\
& $(1.00)$ & $(6.68)$ & $(3.21)$ \\
Illinois, other & $-0.538^{* * *}$ & $1.715^{* * *}$ & $0.469^{* * *}$ \\
& $(3.15)$ & $(8.76)$ & $(3.29)$ \\
Wisconsin & $-0.653^{* * *}$ & $0.840^{* * *}$ & -0.141 \\
& $(4.32)$ & $(4.82)$ & $(1.11)$ \\
\hline
\end{tabular}

Notes: Logit coefficients. $\mathrm{N}=36,605$. Each estimation includes 59 control variables for individual services. Absolute value of $\mathrm{z}$ statistics in parentheses (clustered standard errors). * $=$ significant at $10 \% ;{ }^{* *}=$ significant at $5 \% ;{ }^{* * *}=$ significant at $1 \% . \mathrm{MSA}=$ Metropolitan Statistical Area. 


\section{Table 6: Plans to Increase Privatization (Logit Model)}

\section{Plans Increase}

Population (thousands)

Population squared

Median household income

Population density

MSA dummy

Future fiscal stress

Current fiscal stress

Population growth

Compares costs

Competitive bids

$\%$ Republican

$$
\begin{gathered}
0.227 * * * \\
(6.76) \\
-0.004 * * *
\end{gathered}
$$

$-0.004$

$(0.61)$

0.045

$(0.46)$

0.138

$(0.53)$

0.054

$(0.23)$
$0.006^{* *}$

(1.96)

$0.477^{*}$

$(1.78)$

$-0.540$

(1.64)

0.003
Plans Increase

$0.227 * * *$

(6.82)

$-0.004 * * *$

$-0.003$

(0.48)

0.040

(0.41)

0.129

(0.49)

0.106

(0.44)

$0.006^{*}$

0.399

(1.51)

$-0.565^{*}$

(1.73)

0.005

(0.22)

(0.31) 
NEPPC Working Paper 08-4

Number of services privatized

Illinois, Cook County

Illinois, other

Wisconsin

0.750

862

0.031

0.630

(1.01)

0.568

Number of observations
Mohr, Deller, and Halstead

0.027

0.623

(1.00)

0.573

0.720

878

Notes: Logit coefficients. The two columns represent estimations using two different measures of fiscal stress. Absolute value of $\mathrm{z}$ statistics in parentheses. ${ }^{*}=$ significant at $10 \%$; $*^{* *}=$ significant at 5\%; ${ }^{* * *}=$ significant at $1 \%$. MSA $=$ Metropolitan Statistical Area. 


\section{Table 7. Satisfaction with Service Provision (Ordered Probit Model) \\ Reported \\ Satisfaction}

Population (thousands)

$-0.014$

(1.41)

Population squared

$0.0005 *$

(1.78)

Median household income

$-0.001$

$(0.48)$

Population density

$-0.007$

$(0.19)$

MSA dummy

0.037

$(0.56)$

Current stress

$-0.287 * * *$

(4.65)

Population growth

0.001

Compares costs

0.012

Competitive bids

0.124

(1.41)

$\%$ Republican

0.003

(0.67) 
Illinois, Cook County $\quad-0.236$

Illinois, other

$-0.232 *$

Wisconsin

$-0.041$

$(0.32)$

Your employees entirely

$0.404^{* * *}$

Your employees in part

$-0.025$

(0.65)

Another govt. or authority

$-0.112 * * *$

Private, not for profit

0.094

(1.34)

Notes: Ordered probit coefficients. $\mathrm{N}=31,310$. Estimation includes full set of 59 control variables for individual services. Absolute value of $\mathrm{z}$ statistics in parentheses (clustered standard errors). ${ }^{*}=$ significant at $10 \% ;{ }^{* *}=$ significant at $5 \% ; * * *=$ significant at $1 \%$. MSA = Metropolitan Statistical Area. 